\title{
Generator Termoelektrik untuk Pengisisan Aki
}

\author{
Shanti Candra Puspita, Hasto Sunarno, dan Bachtera Indarto* \\ Departmen Fisika-FMIPA, Institut Teknologi Sepuluh Nopember(ITS), Kampus ITS, Sukolilo, Surabaya, 61111
}

Intisari

Telah dilakukan penelitian tentang generator termoelektrik untuk pengisian aki, dengan tujuan untuk mengetahui dampak perbedaan penggunaan sield (kerangka sistem pemanas) antara triplek dan alumunium pada sistem pemanas TEG. Disamping itu juga untuk mengetahui berapa lama waktu yang dibutuhkan untuk pengisian aki sebagai pengaplikasian TEG. Penelitian ini difokuskan pada pembuatan sistem pemanas yang lebih efisien, yang dilakukan dengan meningkatkan efisiensi dari modul TEG dalam menghasilkan tegangan. Hasil penelitian ini menunjukkan pembaruan sistem pemanas dengan menggunakan sield alumunium dapat meningkatkan tegangan keluaran generator termoelektrik sebesar 4,435\% dibandingkan dengan hasil penelitian sebelumnya dengan menggunakan TEG tipe SP184827145SA. Sedangkan pada pengaplikasian pengisian aki menggunakan TGPR$1 \mathrm{~W}-2 \mathrm{~V}-21 \mathrm{~S}$ dapat menghasilkan tegangan sebesar $6 \pm 0,05$ Volt dengan besar arus $0,43 \pm 0,015$ Ampere yang memerlukan lama waktu pengisian 10 jam.

\begin{abstract}
Research on termoelectric generator for accu charging has been done to know the effect of different use of sield (heating system framework) between plywood and aluminum on TEG heating system. Besides that also to know how much time needed for charging accu as TEG application. This research is focused on making more efficient heating systems, which is done by increasing the efficiency of the TEG module in generating voltage. In this research, it can be concluded that the update of heating system using Alumunium sield can increase the output voltage of the thermoelectric generator by $4.435 \%$ compared to the previous research using TEG type SP184827145SA. While the application of charging Accu using TGPR-1W-2V-21S can produce a voltage of 6 \pm 0.05 Volt with a currentof $0.43 \pm 0.015$ Ampere which requires a duration of charging time of 10 hours.
\end{abstract}

KATA KUNCI: termoelectric generator, heating systems, accu http://dx.doi.org/10.12962/j24604682.

\section{PENDAHULUAN}

Dalam pengertian umum, energi adalah suatu kemampuan dalam melakukan kerja. Energi merupakan suatu obyek yang dapat berpindah akibat adanya reaksi fundamental, tetapi energi tidak dapat diciptakan maupun dimusnahkan. Kini ketersediaan energi di Indonesia semakin berkurang. Hal ini disebabkan oleh berkurangnya sumber energi, akibat adanya ketidakseimbangan antara kebutuhan dengan jumlah energi yang tersedia. Pada perkembangan teknologi kini, banyak dicanangkan berbagai energi alternatif dan energi baru terbarukan untuk mengurangi dampak terjadinya pemanasan global. Namun ketersediaan sumber energi baru terbarukan di Indonesia masih belum termanfaatkan secara maksimal. Penelitian ini dilakukan berdasar pemanfaatan sumber energi baru terbarukan, khususnya panas bumi untuk menghasilkan energi listrik, yaitu menggunakan generator termoelektrik (TEG) sebagai sumber energi alternatif. Generator termoelektrik dapat mengkonversikan perbedaan temperatur menjadi besaran listrik secara langsung namun TEG masih memiliki beberapa kekurangan, yakni memiliki nilai efisiensi yang rendah yaitu $10 \%$. Hal-hal yang membuat efisiensi berkurang adalah panas yang dikonveksikan pada TEG tidak terserap se-

\footnotetext{
*E-MAIL: bachtera@physics.its.ac.id
}

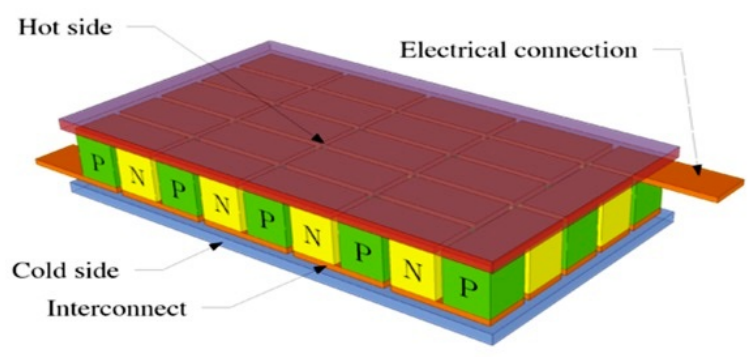

Gambar 1: Susunan semikonduktor pada termoelektrik.

cara sempurna serta sistem pendinginan yang tidak sempurna sehingga TEG tidak dapat bekerja secara maksimal. Hal tersebut yang mendasari penelitian ini, yaitu merancang sistem isolasi panas untuk memaksimalkan kerja modul TEG. Selain itu, dilakukan pemanfaatan hasil daya listrik untuk pengisian aki sebagai penghasil energi alternatif [1].

Termoelektrik merupakan suatu alat yang berbentuk modul, yang dapat secara langsung mengubah energi panas menjadi energi listrik. Termoelektrik terbuat dari bahan semikonduktor yang tersusun dengan komposisi tipe-n dan tipe-p disusun seperti ditunjukkan Gambar 1.

Fenomena termoelektrik ditemukan tahun 1821 untuk pertamakalinya oleh ilmuwan Jerman yaitu Thomas Johann Seebeck. Thomas Seebeck mencoba menyambungkan tembaga dan besi pada suatu rangkaian. Kemudian diantara logam 


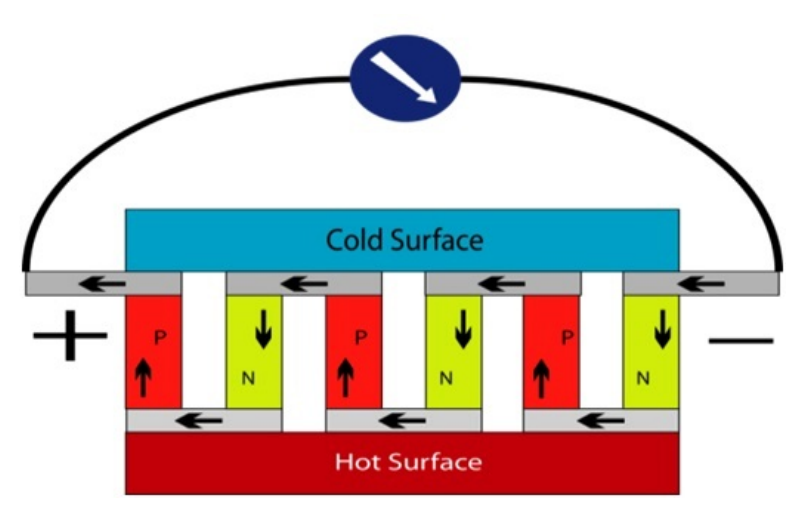

Gambar 2: Prinsip kerja TEG.

tembaga dan besi tersebut diletakkan sebuah jarum kompas. Fenomena yang terjadi saat kedua logam tersebut dipanaskan yaitu jarum kompas mulai bergerak. Bergeraknya jarum kompas menyatakan bahwa timbul medan listrik pada kedua logam tersebut akibat dipanaskan salah satu sisinya, oleh karena hal itu, fenomena tersebut disebut efek Seebeck [1].

Gambar 2 menunjukkan prinsip kerja generator termoelektrik, material penyusun termoelektrik memiliki peran masingmasing untuk mengalirkan energi panas sehingga dapat menimbulkan beda potensial. Disimpulkan bahwa panas atau kalor pada salah satu sisi dialirkan dan dibuang kesisi lainnya, sehingga terjadi aliran arus, ketika terjadi arus maka terciptalah beda potensial yang memunculkan nilai tegangan listrik. Pada termoelektrik besarnya nilai tegangan adalah sebanding dengan gradient temperature [2]. Nilai beda potensial atau tegangan yang dihasilkan berubah sebanding dengan perubahan temperatur, karena semakin besar temperatur maka semakin besar pula tegangan yang dihasilkan [3]. Konstanta kesebandingannya disebut dengan koefisien Seebeck $(\alpha)$,

$$
\alpha=\frac{\Delta V}{\Delta T}
$$

dengan $\alpha$ adalah koefisien Seebeck $\left(\mathrm{mV} / \mathrm{K},{ }^{\circ} \mathrm{C}\right), \Delta \mathrm{V}$ adalah beda potensial $(\mathrm{mV})$, dan $\Delta \mathrm{T}$ adalah perbedaan temperatur $\left(\mathrm{K},{ }^{\circ} \mathrm{C}\right)$

\section{METODE PENELITIAN}

Langkah awal adalah membuat sistem pemanas yang terisolasi oleh isolator panas, sehingga pemanas dapat memberi temperatur panas yang homogen untuk mengaktifkan sistem kerja TEG. Setelah itu dilakukan percobaan dengan mengisi sebuah baterai atau aki untuk mendapatkan daya yang dihasilkan oleh generator termoelektrik dengan variasi waktu tertentu.

\section{Perancangan sistem}

Perancangan alat meliputi perangkat keras maupun perangkat lunak. Sistem perangkat keras terdiri dari sistem pemanas

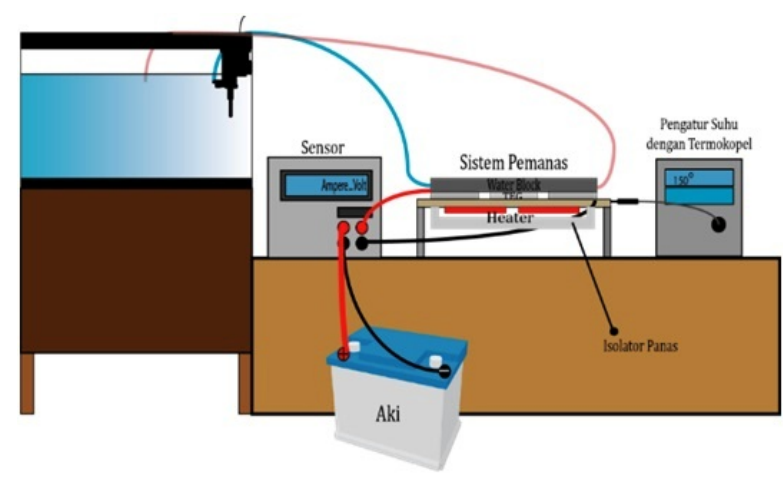

Gambar 3: Rancang bangun sistem.

generator termoelektrik (TEG), sistem pendingin dengan $w a-$ terblock, serta alat ukur yaitu sensor tegangan, sensor arus, dan sensor temperatur. Sistem perangkat lunak terdiri dari perancangan program serta perintah menggunakan mikrokontroler Arduino Uno dengan Atmega 328 sebagai IC-nya sebagai penyimpan data yang dimuat pada SD-card sebagai data logger. Pada penelitian ini, alat yang dibuat dan dirancang secara skematis ditunjukkan Gambar 3.

Gambar 3 terdiri dari sistem pemanas, sistem pendingin, sistem alat ukur, serta aki. Sistem pemanas terdiri dari plat tembaga dengan sield alumunium yang diberi isolator panas. Sumber kalor dari sistem pemanas menggunakan heater strip 350 watt, dengan kontrol panas menggunakan thermostat, yang digunakan pada permukaan panas TEG. Sistem pendingin menggunakan waterblock yang digunakan pada permukaan dingin TEG. Sistem alat ukur terdiri dari sensor arus, sensor tegangan, dan dua sensor temperatur. Tegangan keluaran TEG kemudian diberi beban resistif sehingga dapat digunakan untuk mengisi aki sesuai dengan spesifikasinya yaitu 6 Volt 4,5 Ah.

\section{Pengambilan data}

Pengambilan data dilakukan untuk mengetahui berapa nilai tegangan serta arus yang dibutuhkan untuk pengisian aki dengan TEG. Diagram alir proses pengambilan data ditunjukkan Gambar 4

\section{HASIL DAN DISKUSI}

\section{Pengujian sistem pemanas}

Pengujian sistem pemanas dilakukan dengan mengukur kestabilan temperatur pada plat tembaga serta mengukur berapa besar temperatur pada kerangka sistem yang sudah diberi isolator panas. Hasil distribusi panas dari sumber heater diukur pada titik-titik tertentu yang kemudian ditentukan daerahdaerah plat tembaga yang memiliki suhu yang homogen.

Hasil pengambilan data sampel panas pada 10 titik sistem pemanas seperti ditunjukkan Tabel I, dengan temperatur heater diatur pada $100^{\circ} \mathrm{C}$. Berdasarkan Tabel I terlihat 


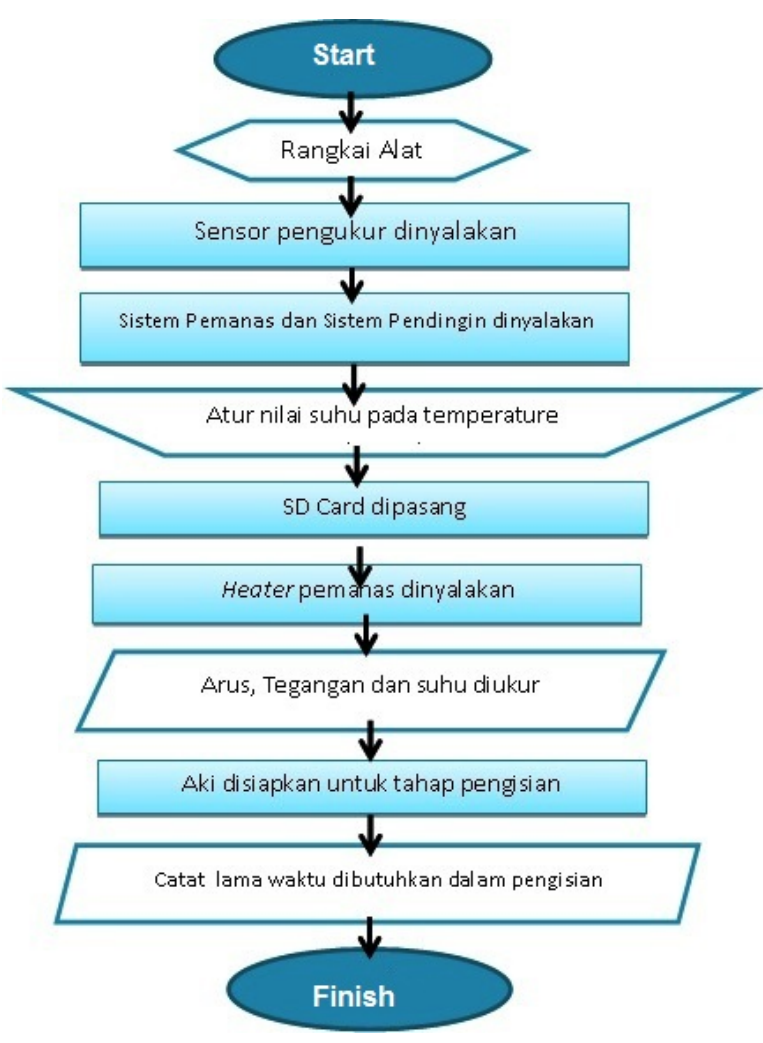

Gambar 4: Diagram alir pengambilan data.

TABEL I: Hasil pengukuran temperatur pada permukaan plat tembaga

\begin{tabular}{ccc}
\hline $\begin{array}{c}\text { Titik sistem } \\
\text { pemanas }\end{array}$ & $\begin{array}{c}\text { Suhu titik } \\
\left({ }^{\circ} \mathrm{C}\right)\end{array}$ & $\begin{array}{c}\Delta \mathrm{T} \text { sumber } \\
\left({ }^{\circ} \mathrm{C}\right)\end{array}$ \\
\hline 1 & 98,9 & 1,1 \\
2 & 97,8 & 2,2 \\
3 & 97,76 & 2,24 \\
4 & 97,85 & 2,15 \\
5 & 97,81 & 2,19 \\
6 & 34 & 66 \\
7 & 34,2 & 65,8 \\
8 & 34,3 & 65,7 \\
9 & 34,12 & 65,88 \\
10 & 86,7 & 13,3 \\
\hline \hline
\end{tabular}

bahwa temperatur yang bersumber dari heater mengalami beberapa penurunan pada masing-masing titik. Titik 1 tempat heater diletakkan mendapatkan panas yang hampir maksimal dengan selisih temperatur dengan sumber heater sebesar $1,1^{\circ} \mathrm{C}$. Sedangkan pada titik $2,3,4$ dan 5 perbedaan dari sumber kalor yang terjadi yaitu sebesar $2,195^{\circ} \mathrm{C}$. Dan diketahui bahwa kerangka sistem yang terisolasi dapat mempertahankan temperatur sumber heater sebesar $66^{\circ} \mathrm{C}$ di dalam sistem sehingga temperatur yang dilepaskan oleh isolator pada lingkungan adalah $34^{\circ} \mathrm{C}$, yang artinya panas dari sumber dapat diredam sebesar $66 \%$. Sedangkan penjepit atas plat tembaga yang terbuat dari alumunium hanya dapat mengurangi panas temperatur sumber sekitar $13 \%$. Pada penelitian ini titik

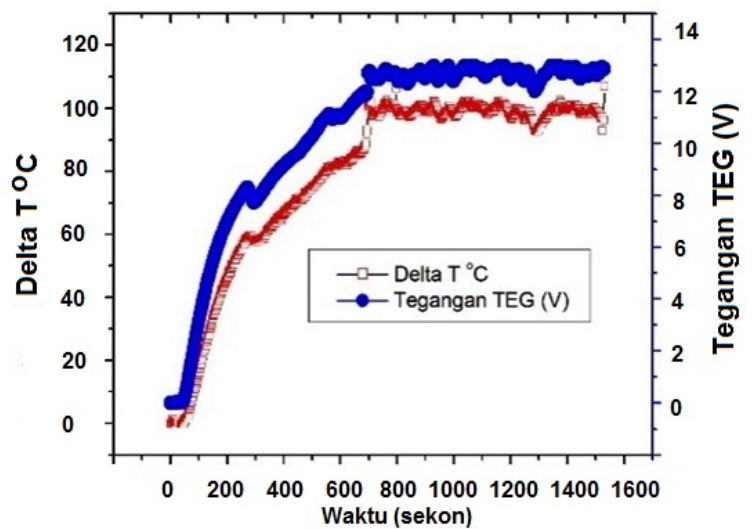

Gambar 5: Karakteristik TEG susun seri pada sistem pemanas kedua dengan $\Delta \mathrm{T}=100^{\circ} \mathrm{C}$.

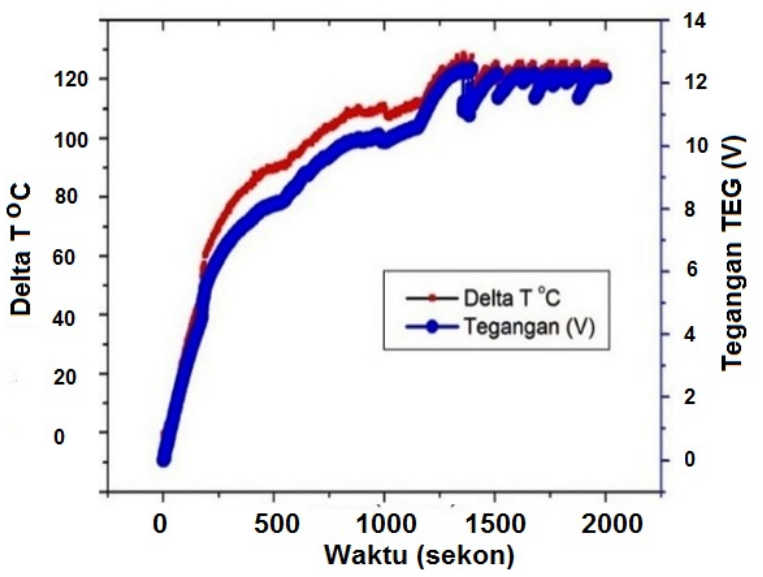

Gambar 6: Karakteristik sistem pemanas kedua dengan $\Delta \mathrm{T}=$ $124,5^{\circ} \mathrm{C}$.

yang digunakan adalah titik 1 dengan besar luasan yang digunakan (60-120) $\mathrm{mm} \times(10-20) \mathrm{mm}$ (dimensi dari 3 modul TEG disusun seri).

\section{Karakterisasi generator termoelektrik}

Mengacu pada penelitian sebelumnya [2], bahwa saat TEG tipe SP184827145SA disusun secara seri sebanyak 3 buah menghasilkan tegangan sebesar $12,4 \mathrm{~V}$ saat $\Delta \mathrm{T}$ sebesar $100^{\circ} \mathrm{C}$. Digunakan sistem pemanas kedua kali ini bertujuan untuk mengetahui apakah terjadi perubahan nilai open voltage pada TEG atau tidak.

Pada Gambar 5 ditunjukkan karakteristik TEG SP184827145SA. Nilai tegangan bertambah saat nilai $\Delta \mathrm{T}$ yaitu $100^{\circ} \mathrm{C}$, yaitu sebesar 12,95 Volt. Hal ini membuktian bahwa efisiensi yang terjadi pada sistem pemanas kedua meningkat, terbukti bahwa beda tegangan output yang terjadi sebesar 4,435\% dari hasil tegangan sebelumnya. Hasil tersebut juga membuktikan bahwa sistem pemanas kedua mampu mempertahankan homogenitas temperatur yang terjadi pada plat tembaga.

Kemudian dilakukan pengambilan data untuk mengetahui daya keluaran modul TGPR-1W-2V-21S. Gambar 6 menun- 


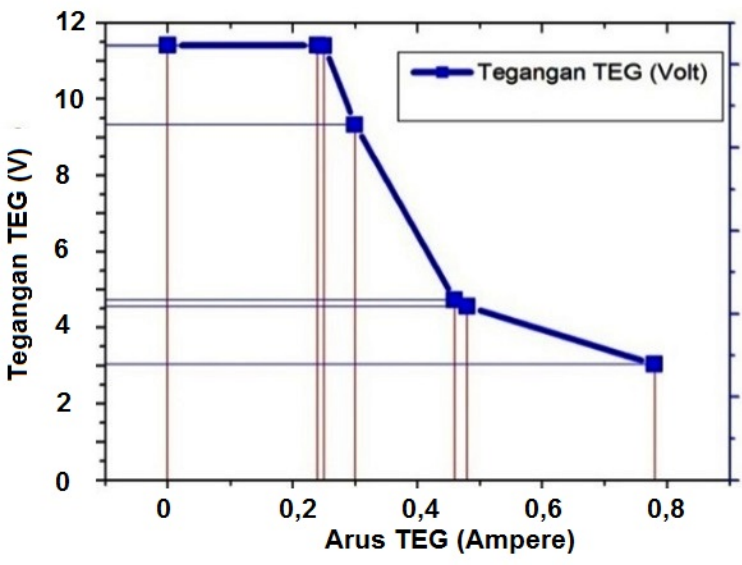

Gambar 7: Kurva pembebanan pada TGPR-1W-2V-21S.

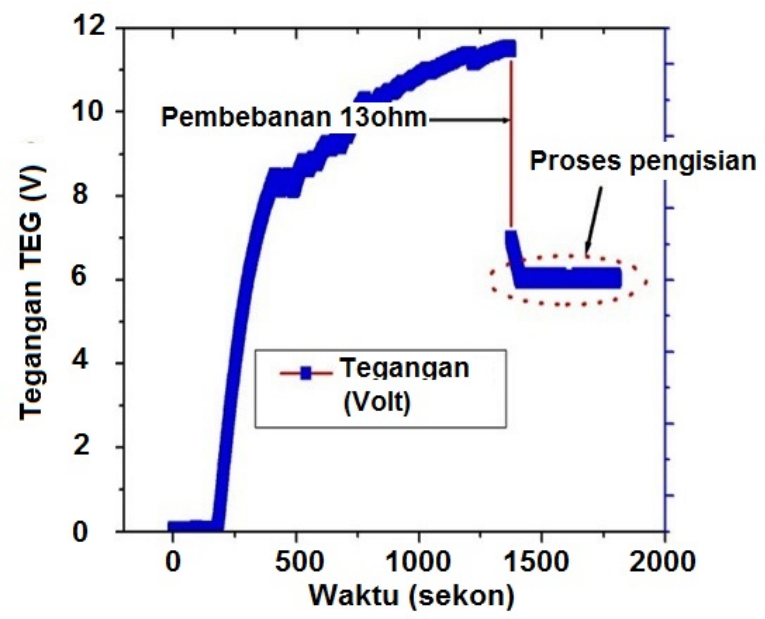

Gambar 8: Kurva pengisian aki.

jukkan grafik keluaran dari TGPR-1W-2V-21S dengan nilai $\Delta \mathrm{T}=124,5^{\circ} \mathrm{C}$ yang distabilkan oleh sistem kontrol pemanas. Modul TEG ini dapat menghasilkan tegangan keluaran sebesar 12,29 Volt saat 3 modul disusun seri. Serta dapat bekerja hingga panas yang diterima TEG mencapai $200^{\circ} \mathrm{C}$ dengan $\mathrm{T}$ hingga $125,25^{\circ} \mathrm{C}$. Selain dilakukan uji kestabilan sistem pemanas, dilakukan pula pengujian terhadap daya keluaran TEG.
Uji pembebanan dengan memberikan beban berupa resistor keramik dengan 6 nilai resistansi yang berbeda.

Gambar 7 menunjukkan kurva pembebanan yang terjadi pada TGPR-1W-2V-21S saat tegangan TEG maksimal yaitu 12,29 Volt. Diperoleh informasi bahwa ketika tegangan dipertahankan pada nilai 11,4 Volt maka arus yang terjadi pada TEG bernilai rendah yaitu 0,224 Ampere. Jika dipertahankan pada tegangan terendahnya 3,03 Volt arus yang terjadi semakin besar yaitu 0,78 Ampere. Berdasarkan kurva pembebanan pada analisis data TGPR-1W-2V-21S, dapat disimpulkan bahwa aki dapat terisi dengan tegangan yaitu 6 Volt dengan posisi besar nilai arus berkisar 0,43-0,45 Ampere. Maka selanjutnya dilakukan pengisian aki dengan pembebanan pada tegangan keluaran menggunakan resistor keramik 13 sesuai dengan perhitungan matematis.

Gambar 8 menunjukkan grafik pengisian baterai dengan jangka waktu yaitu 30 menit (1800 sekon). TEG dikondisikan mencapai tegangan maksimal, kemudian diberibeban sesuai dengan perhitungan matematis lalu dilakukan untuk pengisian aki. Pada penelitian ini hanya dilakukan pengisian selama 30 menit bertujuan untuk mengetahui bagaimana sistem dapat member tegangan konstan untuk pengisian aki. Waktu yang diperlukan berkisar antara 10 hingga 11 jam untuk pengisian agar aki 6 Volt 4,5Ah dapat terisi penuh, hal ini ditinjau dari daya yang dihasilkan aki sebesar 27 Watt, sedangkan daya output TEG saat 6 Volt dan 0,43 Ampere hanya berkisar 2,52,58 Watt. Arus keluaran dan tegangan yang dihasilkan oleh TEG sudah sesuai dengan spesifikasi pengisian aki, yaitu $10 \%$ dari kapasitas arus aki. Sehingga daya keluaran dari TEG ini dapat digunakan untuk pengisian aki.

\section{SIMPULAN}

Pembaruan sistem pemanas dengan menggunakan sield alumunium dapat meningkatkan tegangan keluaran generator termoelektrik sebesar 4,435\% dari penelitian sebelumnya dengan menggunakan SP184827145SA yaitu sebesar 0,55 \pm 0,05 Volt (dengan toleransi alat ukur 5\% atau 0,05 Volt), dan pengisian aki dengan menggunakan TGPR-1W-2V-21S dapat menghasilkan tegangan sebesar $6 \pm 0,05$ Volt dengan besar arus 0,43 $\pm 0,015$ Ampere yang memerlukan lama waktu pengisian 10jam.
[1] X.F. Zheng, C.X. Liu, Y.Y. Yan,Q.Wang, A Review of Thermoelectrics Research Recent Developments and Potentials for Sustainable and Renewable Energy Applications (Nottingham NG7 2RD, UK, 2014).

[2] M. Abrar, Studi Karakterisasi Modul Generator Thermoelektrik Tipe SP184827145SA, Tugas Akhir, Fisika-FMIPA, ITSSurabaya, 2016.
[3] N. Putra, R.A. Koestoer, M. Adhitya, Ardian Roekettino, dan Bayu Trianto, Potensi Pembangkit Daya Thermoelektrik Untuk Kendaraan Hibrid, Depok 16424, Indonesia, 2009.

[4] G.J. Snyder, Small Thermoelectric Generators (The Electrochemical Society Interface, Fall, 2008). 